\title{
Arepresentação da mulher em três poemas de Jorge de Lima
}

Luciene Lemos de Campos*

Luciano Rodrigues Duarte*

Parte de uma pesquisa mais ampla a respeito da mulher e do feminino na poesia brasileira, este texto pretende apresentar algumas reflexões, com interface entre Literatura e História, sobre a representação da figura feminina em três poemas de Jorge de Lima: "Essa negra Fulô" (Novos Poemas, 1928), "Mulher proletária" (Poemas Escolhidos, 1932) e "Marta e Maria" (A Túnica inconsútil, 1938).

Palavras chaves: Literatura Brasileira - História - Jorge de Lima

Part of a larger study about women and women in Brazilian poetry, this paper aims to present some reflections with the interface between literature and history, on the representation of the female figure on three poems by Jorge de Lima, "That black Fulô "(New Poems, 1928)," Women proletarian "(Selected Poems, 1932) and" Martha and Mary "(The seamless tunic, 1938).

Keywords: Brazilian Literature - History Jorge de Lima

\section{Introdução}

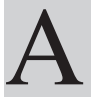
latitude semântica do termo mulher alcançou dimensões simbólicas ao longo dos tempos. Em latim, significa mulier, ser humano adulto do sexo feminino, palavra polissêmica, que remete a inúmeros significados menina, moça, senhorita ou senhora - entre outras terminologias que, por muito tempo, foram utilizadas para determinar e indicar as funções culturais exercidas pelas pessoas do sexo feminino na sociedade. A palavra mulher possui uma pluralidade ímpar de significados e à figura feminina estão associadas imagens que vão de Natureza, Justiça, Liberdade à sedução e morte.

\footnotetext{
* Mestre em Estudos Fronteiriços UFMS. Professora de Língua Portuguesa SED/MS. E-mail: lucienelemos10@yahoo.com.br.

** Mestre em Estudos Fronteiriços UFMS. Professor de História na cidade de Corumbá. E-mail: luciano01rodrigues@yahoo.com.br.
} 
A mulher sempre exerceu papel imprescindível na sociedade, embora ainda hoje ela não tenha os seus direitos plenamente respeitados. Em decorrência disso, muitos são os movimentos e manifestações sociais em que se percebem, cada vez mais, a participação ativa do sexo feminino. Para refletirmos a esse respeito, utilizando-nos do método de pesquisa bibliográfica, fazemos estudo interdisciplinar na interface da História com a Literatura, a partir de três poemas do escritor brasileiro, Jorge de Lima.

Antes de passarmos às reflexões e análise dos poemas: "Essa negra Fulô" (Novos Poemas, 1928), "Mulher proletária" (Poemas Escolhidos, 1932) e "Marta e Maria" (A Túnica inconsútil, 1938), cabe-nos um breve resgate histórico acerca do papel da mulher nas sociedades.

\section{Amulher nas sociedades}

$\mathrm{Na}$ Antiguidade Clássica, as grandes sociedades eram voltadas apenas para os homens e as mulheres eram "utilizadas" para a procriação. A Grécia, por exemplo, apresentou em suas pólis ${ }^{1}$ uma forma de governo, politikón ${ }^{2}$, exercido por homens denominados basilikón ${ }^{3}$.

Conforme afirma Aristóteles no livro I de sua obra Política:

A natureza distinguiu a mulher e do escravo, por que não age de modo avaro, como os artífices (technites) de Delfos, que fazem facas para diversos fins; ela designa um fim específico para cada coisa. $\mathrm{O}$ instrumento mais perfeito não é o que serva para vários usos, mas para aquele que lhe é próprio. Mas, entre os bárbaros, a mulher e o escravo confundem-se na mesma classe, porque lá não existe alguém que por natureza possa comandar: é uma comunidade de escravos dos dois sexos. (...) e foi com razão que Hesíodo disse que a primeira família foi composta "pela mulher e o boi feito para o labor". (grifos nossos).

\footnotetext{
${ }^{1}$ Comunidades independentes denominadas como pólis ou Cidades - Estados. As quais tinham como ponto central a acrópole, parte mais alta da povoação, governada pelo conselho de aristocratas, ou eupátridas.

${ }^{2}$ Governo exercido por um magistrado.

${ }^{3}$ Rei ou chefe de família.
} 
Aristóteles afirma que as sociedades teriam que ser governadas por um rei, e as famílias por um componente mais velho, um patriarca. Nisso, baliza-se em Homero quando acrescenta:

Cada varão, de montes em cavernas, Rege absoluto filhos e mulheres, Vizinhos olvidando. Ilha daquela tanto ou quanto remota, umbrosa estende-se Altriz de agrestes cabras: nunca pisa 90 Humano pé, campônio, zegalejo, Ou caçador ao serra e à fraga atreito; Berrantes fatos inarada pasce.

Nesse sentido, percebemos um antagonismo no sentido de democracia para os atenienses, pois desse direito deixavam excluídos: escravos, estrangeiros, crianças e mulheres. Observamos que, dentro da sociedade Clássica Ateniense, a exclusão feminina se assentava na "inferioridade natural" reservada a esse sexo.

A antiga civilização romana também se erigiu como uma sociedade em que as decisões políticas, sociais e culturais estavam consubstancialmente voltadas aos homens. Assim, as sociedades antigas formaram-se hierarquizadas, tendo em sua maioria um poder patriarcal, o qual subjugou de tal modo o universo feminino que até mesmo o sangue menstrual foi por muito tempo considerado maligno.

O pesquisador Carlos Roberto Figueiredo Nogueira (1998), em seu trabalho intitulado Sexualidade e desejo: as feiticeiras de Castela, afirma que o período medieval arraigou uma sociedade patriarcal, onde a figura feminina era enfaticamente reprimida, e controlada pela ortodoxia cristã. O movimento Renascentista - que de forma geral foi uma imposição à Idade Média - propiciou ao homem diferentes concepções sobre o mundo, mas ainda aí é possível verificar que as mulheres têm um papel marginalizado.

O grande ícone de "perfeição" de mulher em épocas antigas - e ainda nos dias correntes - é a imagem da virgem Maria ${ }^{4}$. Para muitos religiosos, essa figura evoca o paradigma da mulher obediente que renuncia a carne, é fiel ao marido e temente a Deus. A historiografia desdobra os principais eventos históricos através de contos, mitos e lendas e, em sua maioria, têm a figura masculina nos principais cenários e papéis de representação ${ }^{5}$.

\footnotetext{
${ }^{4}$ Para o Catolicismo e para os fiéis de Virgem Maria, ela representa um modelo a ser imitado.

${ }^{5}$ Não desconsideramos aqui o empenho de Joana D'arc, Elizabeth I entre outras figuras femininas históricas, mas fica evidente que a história na maioria das sociedades tem o homem com protagonista.
} 
No período contemporâneo, houve uma significativa abertura para as causas femininas, principalmente no que tange à Revolução Industrial ${ }^{6}$ na Inglaterra, na segunda metade do século XIX. É quando se percebe a inserção de mulheres no mundo do trabalho e a consequente exploração dessa mão de obra. Nesse contexto, as mulheres gradativamente deixam de representar papéis pré-determinados: o de servir o marido e seus filhos ${ }^{7}$, para assumir novos papéis sociais.

A presença da mulher se fez sentir em todas as sociedades constituídas e suas funções foram sendo "adaptadas" às características de cada tempo histórico, no Brasil isso não foi diferente.

Carlos Martins Júnior, no artigo $O$ esforço de construção de representações femininas idealizadas nos jornais mato-grossenses no Estado Novo, anota o seguinte:

Pouco a pouco, as conquistas femininas no exterior repercutiam no Brasil, com o próprio Governo Provisório acatando algumas de suas reivindicações. Em 1932, durante as eleições para a Assembléia Constituinte, foi concedido o direito de voto às mulheres. Na Constituição de 1934, a participação feminina na política se acentuou e vários artigos da Constituição viriam a beneficiá-las, a exemplo da regulamentação do trabalho feminino já previsto nos Decretos Leis de 17 de maio de $1932^{8}$.

Após um longo período de hostilidades, preconceitos e opressão, os movimentos feministas ganham força, principalmente na passagem dos séculos XIX para o XX, onde as mulheres ganham direito a participarem do Sufrágio Univer$\mathrm{sal}^{9}$. Além disso, no Brasil, a nosso ver, uma das grandes conquistas femininas foi a Lei Maria da Penha ${ }^{10}$. Mesmo que alguns de seus direitos estejam garanti-

${ }^{6}$ Processo de transformações econômicas e sociais, caracterizadas pela aceleração do processo produtivo e pela consolidação da produção capitalista.

7 Não desconsideramos a exploração do trabalho feminino das sociedades industriais.

${ }^{8}$ MARTINS JR, Carlos, TRUBILIANO, Carlos Alexandre Barros. O esforço de construção de representações femininas idealizadas nos jornais mato-grossenses no Estado Novo. In: BORGES, Maria Celma, OLIVEIRA, Vitor Wagner Neto de. (Orgs.). Cultura, trabalho e memória: faces da pesquisa em Mato Grosso do Sul. Campo Grande: UFMS, 2006, p. 117 - 133.

${ }^{9}$ Não seria demais lembrar que a Nova Zelândia foi o primeiro país do mundo a conceder o direito ao voto feminino em 1893. A Austrália concedeu o voto feminino em 1902, mas com algumas restrições. No Velho Continente, o primeiro país que permitiu direito ao voto foi a Finlândia em 1906.

${ }^{10}$ LEI 11.340, de 7 de agosto de 2006. Disponível em www.planalto.gov.br, acesso em 18/3/2010. 
dos na Constituição, no mercado de trabalho brasileiro, são explícitas as disparidades salariais entre homens e mulheres.

De um modo geral, ainda que muitos movimentos sociais, políticos e teóricos já tenham se debruçado sobre o papel da mulher na sociedade, esse tema segue instigando estudiosos no sentido de desvelar o que se mantém oculto ${ }^{11}$.

\section{A representação da mulherem três poemas de Jorge Lima}

O poeta brasileiro, Jorge de Lima, nasceu em União, Alagoas, em 23 de abril de 1893, e faleceu no Rio de Janeiro, em 16 de novembro de 1953. Foi médico, pintor, ficcionista e, principalmente, poeta. "Ainda não valorizado com justeza pela criação de uma prosa visionária do sobrenatural, que Tristão de Athayde considera tão grande quanto a poesia" ${ }^{2}$, Jorge de Lima é poeta de múltiplas tendências, palmilhou quase todos os caminhos literários ${ }^{13}$ : iniciou sua carreira com uma série de XIV poemas alexandrinos (1914), de influência parnasiana, atingiu, em obras posteriores, moldes clássicos, neo-simbolistas e engajou-se às propostas modernistas, tendo ultrapassado, em alguns aspectos, seus contemporâneos no que tange aos recursos estéticos empregados em seus poemas. Jorge de Lima fez uso do verso livre, da linguagem coloquial e das referências à vida cotidiana (sobretudo a nordestina), sob a ótica do menino branco marcado pela infância no engenho e pelo profissional, médico e professor, que conviveu com as mais diversas camadas da sociedade. Através de sua obra poética, traduziu anseios e conflitos de seu tempo, sem que a convenção literária e os modismos o arrastassem a versos tais. Jorge de Lima passou dos motivos de infância para os

\footnotetext{
${ }^{11}$ Em sua obra Singularidades Femininas [Singularidades femininas: tecendo alguns fios do devirfeminino. Taubaté, SP: Cabral Ed. Universitária, 1999], Jurema Teixeira comenta que Freud "levou a sério a palavra da mulher" e, a partir das suas histórias, construiu a psicanálise.

12 NEJAR, Carlos. História da literature brasileira: da Carta de Caminha aos contemporaneous. São Paulo: Leya, 2011, p. 395.

${ }^{13}$ Expressão empregada por Fausto Cunha em O livro de sonetos de Jorge de Lima, p. 94. In: LIMA, Jorge de. Poesia completa. (Org.), Alexei Bueno; textos críticos, Marco Lucchesi... [et al.]. Rio de Janeiro: Nova Aguilar, 1997.
} 
regionais, desses para os religiosos e sociais, para, depois, "abandonar qualquer pretexto que não fosse a expressão da sua vida interior". ${ }^{14}$

Com os Poemas negros, Jorge de Lima volta-se à preocupação social e ao interesse pela cultura popular, ao mesmo tempo em que pesquisa a linguagem e os mitos da cultura afrodescendente, de certa maneira, denuncia o processo de marginalização sofrido pelos negros no Brasil. Entretanto, acerca desse assunto, não há consenso entre os estudiosos de sua obra. O que há de admirável no poeta Jorge de Lima é justamente ter conseguido autocrítica para não se prender aos modismos em voga. Seus poemas são produtos de um labor poético diferenciado e inédito.

Em parceria com o amigo Murilo Mendes, lança, em 1935, Tempo e eternidade, em que substitui a expressão regional pela tradição cristã, temática que também aparece em A túnica inconsútil (1938) e em Encontro de Mira-Celi (1950). A partir do Livro de sonetos (1949), a obra de Jorge de Lima caminha para a incorporação do surrealismo como modo de elaboração dos versos, dando inicio à pesquisa poética que culminaria em Invenção de Orfeu (1952), obra citada pelos estudiosos da sua poética, como de complexa mescla entre o real e o sobrenatural, o material, o espiritual e o mítico, "epopéia fantástica".

Lucchesi ${ }^{15}$ comenta o seguinte sobre a produção desse poeta:

A obra de Jorge de Lima permanece robusta e poderosa como um penhasco, na solidão incomparável de seu gênio. Pura altitude, como os céus de Goethe e os abismos de Dante, desafiando nossa condição de leitores borgianos, tocados pela sua poesia escandalosamente bela, tal como a considerou Mário de Andrade, que percebia em Jorge de Lima uma escassa invenção, infinitamente compensada por uma imaginação vasta, profunda, e que fazia dele 'o caso mais apaixonante da poesia contemporânea do Brasil’(grifo do autor).

Diante desse comentário e sabendo-se que o decurso histórico não está à mercê $\hat{e}^{16}$, nem à revelia da produção literária, a poesia jorgiana - assim nos parece - sintetiza o período histórico e as experiências vividas pelo homem Jorge Ma-

${ }^{14}$ DUTRA, Waltensir. Descoberta, Integração e Plenitude de Orfeu, p. 137. In: Jorge de Lima. Poesia Completa. Textos críticos. Rio de Janeiro: Nova Aguilar, 1997.

${ }^{15}$ LUCCHESI, Marco. O sistema Jorge Lima, In LIMA, Jorge de. Op. cit., p. 15.

${ }^{16} \mathrm{O}$ autor tampouco está à mercê ou à revelia do decurso histórico. 
teus de Lima, mesclando-os às memórias do sujeito lírico - reiterado em muitos dos seus versos -, às "inoculações" estéticas engendradas pelo poeta, Jorge de Lima, que as compila em único arcabouço.

Essa totalidade de experiências, tanto pelo comprometimento social e cultural quanto pelas pesquisas estéticas realizadas, é convertida em matéria de muitos de seus escritos, a exemplo do que se depreende dos poemas: Essa negra Fulô (Novos Poemas, 1928), Mulher proletária (Poemas Escolhidos, 1932) e Marta e Maria (A Túnica inconsútil, 1938).

Conforme já observara Chesterton, "O grande poeta existe para mostrar ao homem pequeno quanto ele é grande"17. A altitude lírica de Jorge de Lima remete-nos aos poemas em que a figura feminina é representada ora sensual, transgressora e fonte de prazer, ora inominada, engrenagem para o sistema capitalista ora virtuosa, um tanto mística ou religiosa, a que tem o dom de "propaga(r) a palavra divina".

Cabe-nos observar que as décadas de 1920-1930 - não será demais lembrar, momento em que se publicaram as três obras selecionadas para este estudo - foram de significativas mudanças políticas e de conquistas femininas no cenário brasileiro - vale destacar a Constituição promulgada em 1934. No entanto, são escassos os trabalhos que tratam da representação da mulher na poesia, especificamente, referentes a esse período histórico. Desse modo, valemo-nos dos livros, Casa Grande \& Senzala e Sobrados \& Mucambos, de Gilberto Freyre, para subsidiar a leitura que fazemos do poema Essa Negra Fulô, do poeta alagoano Jorge de Lima.

Na descrição que Gilberto Freyre faz da mulher negra, nessas suas duas obras, enfatiza o sensualismo e "a depravação com a sua docilidade de escrava; abrindo as pernas ao primeiro desejo do sinhô-moço. Desejo, não: ordem"18. É o que um leitor menos avisado, numa primeira leitura, pode interpretar do poema Essa negra Fulô.

Publicado em edição limitada, em Maceió, pela primeira vez em 1928 e, no mesmo ano, no Rio de Janeiro, compõe a obra Novos Poemas. Talvez, dentre

\footnotetext{
${ }^{17}$ Apud NEJAR, Carlos. Op. cit., p. 405.

${ }^{18}$ FREYRE, Gilberto. Casa Grande \& Senzala: formação da família brasileira sob o regime de economia patriarcal. 50 ed. São Paulo: Global, 2005, p. 456.
} 
a produção de Jorge de Lima, seja o Essa Negra Fulô o mais aclamado e citado em trabalhos acadêmicos e de organizadores de antologias.

Nesse poema, Jorge de Lima usa linguagem coloquial em franca inobservância da norma padrão culta. Notam-se, por exemplo, reduções vocabulares - "dum", "Fulô", "pra”, "pro", "Sinhô", "Sinhá" e "cadê" - empregam-se, também, expressões populares como: "levar couro", "que nem” e "nuinha", para citarmos alguns dos recursos empregados. Evidente é o trabalho com a seleção de palavras, como também é recorrente o uso da intertextualidade. Parece-nos que, no poema, embora Jorge de Lima use e abuse das marcas da oralidade e da facilidade cadencial dos versos, não há banalidade temática ou estética. O poeta busca, assim, produzir uma literatura própria do Brasil. Desse modo, o poeta faz interlocuções com narrativas do domínio popular, "vestindo" o poema com as coisas e cores de seu território, ao mesmo tempo em que "dá uma piscadela" para o leitor, revelando a intenção poética. É o que aparece, especificamente, nestes versos: "pelos figos da figueira/ que o Sabiá beliscou", os quais remetem aos anotados por Luís da Câmara Cascudo no conto A menina que foi enterrada viva: "Pelo figo da figueira / Que o passarinho bicou..."19. Ora, "o Sabiá", substantivo comum, empregado em maiúscula, no poema jorgiano, nos remete a quê? Certamente, a escolha do substantivo comum sabiá, empregado no poema como substantivo próprio, não é gratuita, já que o "Sabià" lembra um grande lírico que "beliscou" as oliveiras portuguesas, ou ainda, as palmeiras.

"Essa Negra Fulô" é poema narrativo, burilado pelo ritmo melódico, marcado pela redondilha maior, predominantemente.

Ora, se deu que chegou

(isso já faz muito tempo)

no bangüê dum meu avô

uma negra bonitinha

chamada negra Fulô.

No plano da expressão, é informado tanto o imaginado quanto o real. Em (isso já faz muito tempo) / no bangüê dum meu avô, o poeta levanta o alçapão da memória para daí fazer emergir narrativas regionais com a propriedade de um contador de casos, de quem as ouviu - no bangüê ou sobre o banguê. Porém,

${ }^{19}$ CASCUDO, Luís da Câmara. Contos tradicionais do Brasil. São Paulo: Ediouro, 2000. 
tais narrativas passam a ser contadas, em tom anedótico por um emissor que se encontra em um tempo e lugar diferenciados do enunciado no poema.

Percebe-se, em "Essa negra Fulô", um entrelaçamento de fios intertextuais passíveis de desdobramentos, através dos quais o poeta minimiza a banalidade da narrativa simples e expressa pensamentos mais elevados acerca das relações sociais existentes. A informação entre parênteses (isso já faz muito tempo [...]) é índice indicativo do tempo em que transcorre a história de "Fulô", um tempo pretérito, remoto, concluído e isso "já faz muito tempo". Logo, a "negra bonitinha", protagonista do poema, pode ser interpretada como a mulher escrava, que de fato existiu, ou como "personagem" inventada pelo poeta, haja vista as informações contidas nos estudos que se publicaram acerca da biografia e do conjunto da obra jorgiana nos darem conta de que o conhecimento literário e a vivência, no ou próximo ao engenho, contribuíram, direta ou indiretamente, para muitas das suas criações literárias.

"Fulô", no poema em estudo, é substantivo próprio reduzido, oriundo do substantivo comum: flor; é personificação da mulher negra que servia as Sinhás nos afazeres domésticos e os Sinhôs nos prazeres da alcova - conforme nos ensina o sociólogo Gilberto Freyre -. Pode remeter, ainda, às mulheres marginalizadas desde os tempos da colonização.

Afinando com esse pensamento, Bastide ${ }^{20}$ nos lembra que

[...] Jorge de Lima tem algo de remorso do assassino. Após haver sustentado que o elemento africano estava fadado a desaparecer, que o Brasil caminhava para uma arianização e um 'embranquecimento' progressivo do sangue, após haver sustentado uma política racial que intensificava a obra de seleção pelo desaparecimento dos mais escuros [...]. Sua poesia vai procurar numa ausência de africano o que subsiste ainda de africano, em piedosa e ao mesmo tempo desesperada peregrinação.

Isso demonstra, a princípio, a disponibilidade de Jorge de Lima para perceber o outro.

Nessa perspectiva, encontramos em Essa negra Fulô o olhar de um eu-poético que se volta ao passado para refletir sobre as relações sociais de outro tempo. Assim, Jorge de Lima - fugindo ao convencional quanto à forma, à linguagem e

${ }^{20}$ BASTIDE, Roger. Poetas do Brasil. São Paulo: USP, 1997, p. 48. 
à temática em voga - desnuda as convenções e contradições sociais em relação à figura feminina no universo patriarcal rural. As duas mulheres que aparecem nesse poema podem ser caracterizadas como figuras subjugadas em um universo patriarcal de há muito enraizado.

De um lado, a Sinhá - representação da mulher do senhor de engenho, de fazenda ou a iaiá de sobrado - revelar em seus gestos certo sedentarismo, como se ela fosse uma figura lânguida, uma "doente" ou "boneca de carne do marido"21. Quanto a isso, a seleção vocabular transforma a "fala da Sinhá" em exemplar da sua inatividade:

Ó Fulô! Ó Fulô!

(Era a fala da Sinhá)

vem me ajudar, ó Fulô,

vem abanar o meu corpo

que estou suada, Fulô!

vem coçar minha coceira,

vem me catar cafuné,

vem balançar minha rede,

vem me contar uma história,

que eu estou com sono, Fulô!

Embora não faça referência direta à questão, o poema pode remeter às relações entre homens e mulheres do Brasil colônia. Isso nos leva a múltiplas interpretações acerca do papel feminino numa sociedade onde somente há poucos anos se admitiu não existir igualdade entre as classificações sociais e quanto aos direitos. Assim, se de um lado a "Sinhá" do engenho se mostrar inativa, de outro, no poema de Jorge de Lima, Fulô representa a mulher transgressora, lúbrica e ágil, tipificada como fonte do prazer tropical, dos desejos libidinosos do Sinhô, aquela que "escurece a vista" do proprietário do bangüê e toma seu Sinhô para si.

Ó fulô? Ó Fulô?

Cadê, cadê teu Sinhô

que nosso Senhor me mandou?

$\mathrm{Ah}$ ! foi você que roubou,

foi você, negra Fulô?

${ }^{21}$ FREYRE, Gilberto. Sobrados e mucambos. Rio de Janeiro: José Olympio, 1962, p. 94. 
Parece-nos que esse poema não se presta de revelar sabores de banguês afro-brasileiros, de empreender bandeira castroalvina em favor da abolição da escravatura. A liberdade que emerge de Essa Negra Fulô, de Jorge de Lima é outra. O feminino é representado por empatia e não por esforço racionalizado. Esse poema que tanta admiração causou a muitas gerações de leitores traz no seu bojo temas que só vieram a ser debatidos há alguns anos depois de sua publicação. A questão da emancipação e os direitos da mulher só passaram a ser discutidos - e levados a sério - na sociedade brasileira, a partir do final do século XX, portanto, muitos anos após a publicação da obra jorgiana.

Nos dizeres de Freyre ${ }^{22}$,

Em Jorge de Lima o verbo fez-se carne [...] no sentido de sua poesia afronordestina ser realmente a expressão carnal do Brasil mais adoçado pela influência do africano. Jorge de Lima não nos fala dos seus irmãos, descendentes de escravos, com resguardos profiláticos de poeta arrogante branco, erudito, acadêmico, a explorar o pitoresco do assunto com olhos distantes de turista ou de curioso. De modo nenhum. Seu verbo se faz carne: carne mestiça. Seu verbo de poeta se torna carnalmente mestiço quando fala de 'democracia' [...], embora a metade aristocrática desse nordestino total, de corpo colorido por jenipapo e marcado por catapora, não esqueça que a 'bisavó dançou uma valsa com D. Pedro II', nem que 'o avô teve banguê'.

Numa sociedade em que havia escravos e a pessoa "decente" não podia trabalhar com as mãos, a agilidade com elas - para a mucama do poema de Jorge de Lima - é fundamental e eficaz. Além de servirem para "forrar a cama", "pentear os cabelos", "catar cafuné", "abanar o corpo" e "ajudar a tirar a roupa" da Sinhà, tiram "a saia" e "o cabeção" da "negra bonitinha", que encanta e deixa o Sinhô em êxtase: "O Sinhô disse: Fulô! / (A vista se escureceu/ que nem a negra Fulô.)", despertando nele, talvez, os desejos mais recônditos:

O Sinhô foi açoitar

sozinho a negra Fulô.

A negra tirou a saia

e tirou o cabeção,

de dentro dele pulou

nuinha a negra Fulô.

${ }^{22}$ FREYRE, Gilberto. Vida, forma e cor. Prefácio de Renato Carneiro Campos. Rio de Janeiro: Record, 1987, p. 42. 
A expressão "tirar o cabeção" conota libertação das rédeas, do cabresto de escrava para, simbolicamente, assumir outro papel social. Quanto a isso, não é, pois, por acaso que no panteão mitológico brasileiro figura Xica da Silva, mucama que transformou em dominado o dominador branco português. Ademais, a gradação dos "roubos": o frasco de cheiro, o lenço de rendas, o cinto, o broche, o terço de ouro, "denunciados" pela Sinhá, encontra correspondência no que anota Gilberto Freyre sobre o sadismo das mulheres quando se trata dos ciúmes delas pelas negras "bonitinhas". Pode-se inferir que, no poema, entre "levar couro do feitor" e "tirar o cabeção", a negra, protagonista do poema jorgiano, faz girar a roda da história, subvertendo o papel destinado às mulheres tidas como submissas nas relações sociais, visto que "tirar a saia", no poema, não parece uma ação imposta ou uma ordem do "Sinhô".

Freyre $^{23}$ lembra, com muita propriedade, que

Experiência brasileira não faltou a Jorge de Lima: ele foi bem do Nordeste. Não lhe faltou o contato com a realidade afro-nordestina. E há poemas seus em que os nossos olhos, os nossos ouvidos, o nosso olfato, o nosso paladar se juntam para saborear gostos e cheiros de carne de mulata, de massapé, de resina, de moqueca, de maresia, de sargaço; para sentir cores e formas regionais que dão presença e vida, e não apenas encanto literário, às sugestões das palavras. Cores, sabores, odores que parecem dar às simples palavras outras condições de vida, além da tecnicamente literária

Dos gostos e cheiros de carne de mulata, de Essa negra Fulô emerge reflexão crítica acerca do papel da mulher na sociedade brasileira daquele e deste século. Tema que o poeta talvez exprima sem revolta acre e sem intenções panfletárias, mas que, nos interstícios do poema, subjaz possibilidade de interpretação. Nesse sentido, Jorge de Lima "enriquece o brasileiro das áreas menos coloridas pela influência africana, com a expressão poética de sua experiência de nordestino de banguê" 24 e, com um olhar à frente de seu tempo, extrai da camada popular algumas das suas protagonistas femininas ou similares a nomes que encarnam o feminino, como é Flor abreviada ou reduzida a: "Fulô".

Enquanto "Fulô", ao que parece, tem inscrição na realidade, a figura feminina invocada no poema Mulher proletária (1932), remete à mecanização da

\footnotetext{
${ }^{23}$ Idem, p. 41.

${ }^{24}$ Idem, p. 43.
} 
mulher em relação ao seu papel social. Trata-se de uma mulher não nomeada, "proletária". Proletária é determinante e condição daquela que trabalha em ofício ou profissão manual em troca de salário. Mas, a "personagem" do poema jorgiano surge como uma peça nas engrenagens da sociedade, ou melhor, é a máquina que fabrica braços para abastecer a superprodução. Desse modo, o uso constante dos fonemas /f/ /s/ e /p/ corroboram para dar ao poema a musicalidade ou reproduzem ruídos que imitam a máquina de fiar.

Eis o poema:

\title{
MULHER PROLETÁRIA
}

\author{
Mulher proletária - única fábrica \\ que o operário tem, (fábrica de filhos) \\ tu \\ na tua superprodução de máquina humana \\ forneces anjos para o Senhor Jesus, \\ forneces braços para o senhor burguês \\ Mulher proletária, \\ O operário, teu proprietário \\ há de ver, há de ver: \\ a tua produção, \\ a tua superprodução, \\ ao contrário das máquinas burguesas \\ salvar teu proprietário ${ }^{25}$.
}

Não se expressa, nesse poema, apenas a representação de uma realidade nem pretende o poeta instaurar a comoção do leitor ou algo similar. Embora possa ser considerado exemplar da prosa, esse poema abriga uma colossal possibilidade de leituras sob o viés da poesia. Ao que parece, há uma voz - a do eu-poético - que denuncia a exploração da mulher, da pessoa humana - para empregarmos um jargão do Direito - em nome da necessidade de superprodução, mola da sociedade que se sustenta em função de desigualdades.

${ }^{25}$ LIMA, Jorge de. Op. cit., pp. 286-287. 
A Mulher proletária é apresentada com certa simpatia pelo emissor. Sob seu olhar, ela é um ser subjugado às convenções da burguesia mecanizada, é vista não como mãe ou esposa, é a própria fábrica que mantém as diferenças impostas pela sociedade à qual pertence. Essa mulher representa o ser que não pertence a si mesmo, é propriedade de outrem tal qual Rousseau definiu em 1755, no Discurso sobre a origem da desigualdade entre os homens. Quanto a isso, nos versos de Jorge de Lima, é possível observar o jogo: proletária - operário - proprietário. O jogo de palavras talvez seja uma dessas possibilidades para adentrarmos a outras questões apresentadas nesse poema. Analisemos, quanto possível, alguns versos do poema:

$$
\begin{aligned}
& \text { Mulher proletária - única fábrica } \\
& \text { que o operário tem, (fábrica de filhos) }
\end{aligned}
$$

À mulher operária parece restar somente a produção de filhos, reduzidos por metonímia: "braços" - força que continuará a mover outras máquinas e perpetuar as relações sociais sempre monótonas e repetidas - . Nesse discurso, se nos detivermos na análise das expressões verbais empregadas: "tem", "forneces", "há de ver", "salvar" o que se apresenta como narrativa ingênua e sem muitas pretensões, possibilita conexões entre assimetrias políticas e as desigualdades socioeconômicas ainda existentes no Brasil. Assim, "operária" subentende mais que uma referência de caráter físico ou um mecanismo de defesa e sobrevivência da espécie: "salvar teu proprietário".

Posto isto, cabe-nos lembrar que Freyre, na obra Vida, forma e cor $^{26}$, afirma o seguinte a respeito de uma "fonte" possível da poética de Jorge de Lima:

Médico de província, cuja miséria observou; cujo sofrimento sentiu com o poder de empatia o anima com relação à sua gente, do mesmo modo que sentiu suas alegrias, suas esperanças, seus deleites doentios de comedores de barro, seus medos das almas do mundo. [...].

Não seria demasiado asseverar que, além da empatia com relação a sua gente cujo sofrimento o poeta-médico pôde observar e sentir, as ideias de Rousseau e Karl Marx também "transbordam” do poema Mulher proletária.

${ }^{26}$ FREYRE, Gilberto. Vida..., op. cit., p. 41. 
Entretanto - assim nos parece - Jorge de Lima não abandona o ato poético em favor, apenas, de uma postura crítica, de uma única causa ou de uma inteligência que se confina na "verborréia", no hermetismo metafórico pleno de enigmas verbais indecifráveis com intenção de impressionar o interlocutor. Nesse poema, há opção por uma pseudo-simplicidade.

Em sintonia com o que anotou ${ }^{27}$ acerca de Invenção de Orfeu - e esses mesmos dizeres podem ser ratificados para o poema em estudo -: "[S]erá preciso esperar que os anos passem e que sucessivas gerações de críticos se debrucem sobre a fábrica imensa" deste grande poema curto, a fim de trazer à tona a história que se encontra dentro da estória desse Mulher proletária, de Jorge de Lima.

Eis algumas possibilidades para que os estudiosos da Literatura Brasileira se debrucem sobre a produção literária desse poeta ímpar: a) nos poemas Essa negra Fulô e Mulher proletária, é possível perceber aproximação entre literatura e história no que tange ao papel representado pela figura feminina; b) talvez tais pesquisas apontem para mudanças no âmbito dos estudos literários, quer no domínio da estética, quer no âmbito da poética, quer na atuação da crítica; c) talvez se comprove o quão à frente de seus contemporâneos está Jorge de Lima com relação às reflexões acerca dos gêneros: poético e de representação social.

Dentre todas as facetas de Jorge de Lima, a de poeta "filosófico-estético" é a que produziu ecos mais duradouros sobre o projeto poético jorgiano. Mas, quanto a isso, ainda há lacunas na sua fortuna crítica e que, para nós, urge serem preenchidas.

Já se disse que Jorge de Lima resgatou a efemeridade da poesia do seu tempo, tentando superar o episódico, o regional e o puramente formal, os modelos de poesia em voga, pelo monumental. A propósito do monumental na poética jorgiana, ousamos afirmar que em "Marta e Maria" (A Túnica inconsútil, 1938) o autor, de certa maneira, revela o segredo de seus versos insinuantes, usando, mais uma vez, de uma pseudo-simplicidade para tratar de temas profundamente humanos e complexos, ao mesmo tempo em que apresenta intertextualidade com textos bíblicos.

Apreciemos o poema:

MARTA E MARIA

Tu tens nas tuas mãos as duas irmãs de Cristo:

a que escreve, a que trabalha, a que propaga a palavra

${ }^{27}$ SIMÕES, João Gaspar. Invenção de Orfeu. In: LIMA, Jorge de. Op. cit., p. 100-101. 
divina, a que louva e proclama a sua glória e a sua

poesia; e a que silenciosa ampara a tua fronte pendida

onde irão cravar uma coroa de espinhos. ${ }^{28}$

Os nomes "Marta" e "Maria" remetem às personagens bíblicas da história da ressurreição de Lázaro. Na narrativa da Bíblia, Cristo recebe uma mensagem de Marta e vai até a casa do amigo. O "Mestre", compadecido da tristeza das duas irmãs (Marta e Maria), realiza o milagre, devolvendo "vida nova" ao amigo morto há quatro dias.

Marta, na história bíblica, é mulher diferente das demais. Representa a figura feminina que está à frente de seu tempo. É aquela que, de algum modo, transgride as regras da sociedade. Nesse sentido, não parece inexpressiva a presença da figura feminina nos poemas jorgianos.

Lima, neste poema, representa a mulher como um ser mítico o qual pode ser associado ao próprio poeta, visto que ambos: escrevem e trabalham a fim de propagarem a palavra divina, a poesia. A poesia é, também, orientação para o interlocutor "tu" a quem a mensagem é transmitida. Assim, ter "as duas irmãs de Cristo" talvez indicie, de modo figurado, uma opção a ser seguida, pois, na narrativa bíblica, enquanto uma irmã fica em casa chorando a morte de Lázaro, a outra vai ao encontro da solução para o problema.

A mulher, em Marta e Maria, é caracterizada pelas ações: "escreve", "trabalha”, "propaga", "louva", "proclama" e "ampara”. Logo, no domínio da expressão, os nomes femininos, nesse poema, se avultam e se completam, ao mesmo tempo em que se tornam enigmas a serem decifrados. Há, nessa criação poética, certa tendência estética ainda não creditada a Jorge de Lima.

No primeiro verso, o poeta informa uma sequência de fonemas constituída de: /t /, /d /, /u/, /a/ e /s /. Além disso, o terceiro e o quarto versos se iniciam com os vocábulos: "divina" e "poesia", respectivamente, recursos que parecem reforçar tendência poética e ideológica impressas, elipticamente, por Jorge de Lima: a poesia é mensagem divina, somada a trabalho, experiência e pesquisa estética.

Nos poemas apresentados neste estudo, há um veio comum de propriedades, de articulações e de formas de organização do discurso que será preciso

${ }^{28}$ Lima, Jorge de. Op. cit., p. 393. 
explorar de forma mais densa, pois a poesia de Jorge de Lima não se limita a reproduzir cenas sociais, religiosas ou discutir questões de gêneros. A ars poética jorgiana abre múltiplas possibilidades para, a partir de diferentes recortes, compreendermos o significado da poesia no âmbito da literatura produzida a partir do século XX, bem como de se analisarem as relações de gêneros e das relações sociais, já que não lhe escapam tais reflexões.

Permite-nos aprofundar a análise, no aspecto que empreendemos nesta leitura, o parecer do crítico Bastide ${ }^{29}$,

Ora, Jorge de Lima é médico. E introduz em sua poesia lembranças profissionais. Seu Deus é um chefe de laboratório que faz experiências; o homem é uma cobaia entre mãos da divindade. No plano humano, parece-nos que essas experiências são do tipo daquelas de Claude Bernard denominava 'experiências para ver', isto é, sem motivo, com o único propósito de observar reações imprevistas $[\ldots]$.

Jorge de Lima doou todas as suas experiências - poéticas, profissionais, místicas, religiosas, as lembranças, o calor do menino e a sensibilidade do adulto que sentiu os sabores e dissabores das periferias -, talvez, em busca de único ideal: a poesia sem as amarras do previamente estabelecido ou convencionado.

Assinalado o modo como Jorge de Lima representa a figura feminina nos três poemas: Essa negra Fulô, Mulher proletária e Marta e Maria, e observado o olhar que a crítica lançou sobre sua obra, acreditamos que a representação da mulher tem enfoque ímpar na poesia jorgiana.

É possível depreender que os poemas de Jorge de Lima conservam vontade consciente de que a poesia seja "o canto de Orfeu que acalma os animais ferozes".

\section{Considerações finais}

Observamos que a mulher, através dos períodos históricos, sofreu as mais diversas formas de (in) diferenças e que as sociedades lhe destinavam o papel de sujeito subjugado. Entretanto, esse passado que por vezes fora silenciado, vem sendo des-velado por estudiosos das mais diversas áreas, quando não dissociam Literatura da História.

${ }^{29}$ BASTIDE, Roger. Op. cit., p. 128. 
A ars poética jorgiana, de marcas essencialmente humanas, sustém um compromisso dos mais profundos. Entre outras definições, é também a expressão das emoções e reflexões do poeta diante do mundo, da desumanização, da mecanização humana, da miséria, da exclusão, das diferenças em geral e da necessidade da Poesia ao lado das necessidades mais elementares. Seus poemas transcendem as formas do discurso, não se deixam reduzir a normas, formas e temas, tampouco se limitam a único viés de leitura, porque esse poeta brasileiro não se prendeu à rivalidade edipiana para com os seus antecessores. Ele desloca, modifica e faz dialogar Poesia e História com os contos populares, narrativas bíblicas e memórias. Edificando, deste modo, arte poética peculiar: um canto novo para se desvelar, dentre outros temas, a representação feminina. 